\title{
Hearing death pronounced
}

\section{Early:}

Somehow his casual hands seem like words and his thick chest like punctuation. Simply, "I'll just be gone a moment," they seem to say. But as you sit nearby, writing notes, an absence lingers. Then you realize the dead man is saying something else. Before you come to this, however, other things will have happened. You will step into the room and there on the bed will lie a body. At best it will be late into the night and, better still, you will be harried and pressed with demands. For then it's easier to set the dead aside as part of a larger duty. Regardless, there will lie a body. There will lie as well the difficulty. For the trouble with these bodies is that they don't care about you, yet they don't ignore you either. Instead, they radiate, like an invisible beacon, the words, "You too." And now and again you will hear it. You too. We two.

Likely, it will all begin much earlier. Often it begins when there is no real speaking. Instead, it begins when actions seem important. You might meet the dead as a not-dead, but dying patient. Wrapped in an ambulance stretcher, maybe breathing into a mask, with a tube running under the sheets. And under the sheets of his chart you will find the message that he is falling. The consults, diagnostics and notes tell that he has passed all crevices and branches that could have given a grip. He is no longer sliding toward the edge, but has fallen over it. You know that the next sound will be of his hitting death.

But you know how this goes. Attend to the other fallings - falling blood pressure, a drop in consciousness, a decreasing respiratory drive, the depressed mood of relatives. And, above all, manage. Manage symptoms, manage expectations, manage hope, man$\therefore$ age to say something. Usually, this is when the dying begin to speak. Not their spoken words - which are about disease and worry and are sometimes confused, always unreal - but the other speaking. You will feel the familiar, distant itch of hope that they die on someone else's time, and the reason for the itch is that somewhere within the dying you begin to sense the growing refrain of "You too."

\section{Late:}

You remember what his wife said. He died around midnight, and if before midnight, he would have died on his birthday. Together you decide that he had died the day after his birthday. More the way he would have wanted it, you think. You pause before starting your notes, lingering. You imagine what will hap-

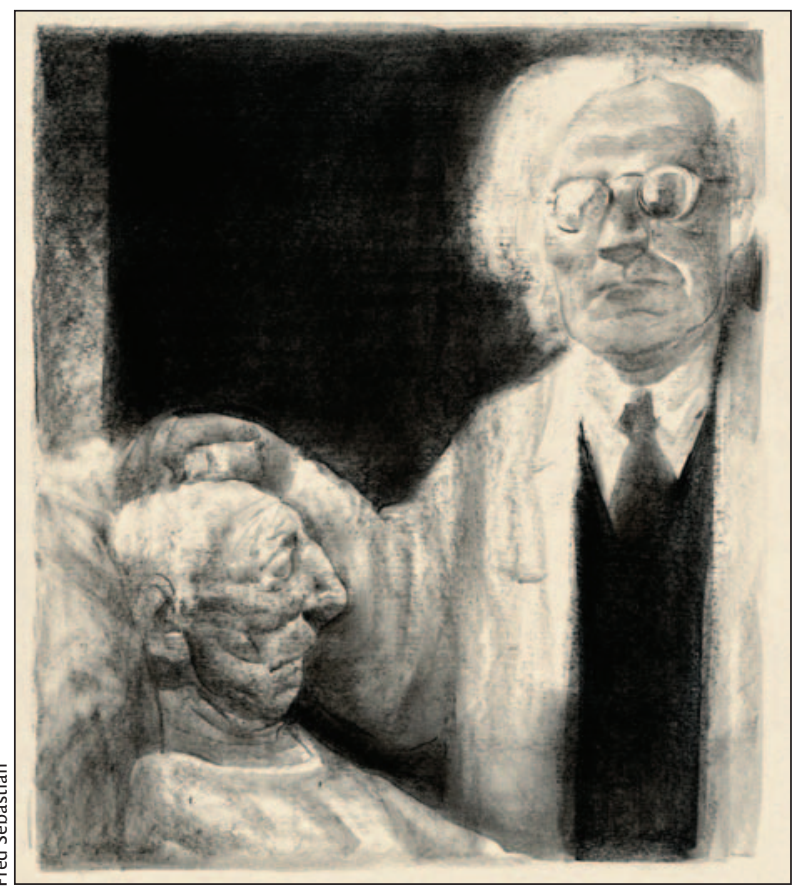
pen before you come to this. You will find yourself in a room, on a bed, a week or so since you last managed to stand, you think. Like a stack of papers pushed from the desk, so the details of your life will fall about you. There will be no way, you realize, to ever pick them up again.

It will all have started much earlier. Months before, another doctor will say "That's enough." But you will have known it already. The goodbyes will be hard. It's hard not to love the life that has given both trouble and so many fine things. Do you remember the children when they were young? Can you recall the worry to become worthwhile, the joy of some afternoons, the sadness of failing your sister? You still love waking in the mornings, you think. Where does one begin to say goodbye to the page, word and index of everything altogether? If she squeezes your hand, then perhaps you can begin. And as you sit together to hear that it is enough, she squeezes your hand.

At first you will think that there are things to do. But then, when even dressing exhausts you, then the papers fall and the details of your life drift into a scatter. Perhaps at last, when you are neither nauseous nor drowsy then an- other life will break the quiet. For that's what I haven't realized until now - not really until now, you will think. That flowing under it all was my second life. And sometimes when my little girl laughed, when my dear wife squeezed my hand and when the night seemed a charm, my second life spoke. You will feel the familiar, distant sigh of hope that you too will die with your wife and children nearby. And if you are lucky, when you cry it will be for having found your second life in time to leave it.

There he lies on the bed, and she says to you, "The strange thing is that somehow, when he knew he was dying it was like a second chance." And you realize again, but this time like you had never heard it before, that we are born with a beacon. The chance of seeing the seconds of a second life is the beacon that draws us on, if only we could really know it.

\section{Victor Cellarius MD MA}

Family and Community Medicine

The Temmy Latner Centre for Palliative Care

Mount Sinai Hospital

Toronto, Ont. 